DE DE GRUYTER OPEN
Journal of Intercultural Management

Vol. 5, No. 3, September 2013, pp. 91-101

DOI 10.2478/joim-2013-0021

Nikolay Ploshchyk

National University of Life and Environmental Sciences of Ukraine

\title{
The world coffee sector under conditions of the second wave of the economic recession
}

\begin{abstract}
This article is devoted to research of tendencies and activities of the world coffee market. The author has described factors that influence the conjuncture of the coffee sector. It's been found out that coffee market, comparatively to other markets, had had less impact from the economic recession. Made forecasting global consumption of coffee in 2015/16 harvest year.
\end{abstract}

Key words: world coffee sector, production, consumption, forecasting, resources, price fluctuations, economic recession.

\section{Introduction}

It is difficult to overestimate the value of the coffee market significance for the vast masses since this product has become a usual part of a common diet. Coffee is an important export product for more than 50 countries. Moreover it is of great economic importance for millions of people who directly or indirectly depend on its production and sales as their main means of leaving.

The world coffee sector is quite a specific market and a whole complex of variable factors and causes influence the current economic state and activities in the market thus changing its conjuncture. And the harvest cyclic recurrence that is made conditional on coffee tree production is just one particular example of such factors.

In terms of understanding the trends of the global food market, the problem of food security and stability of agricultural markets is extremely important and relevant. 
Based on the foregoing and given the enormous economic importance of coffee, the study of selected issues is highly actual and timely.

Researches of the world coffee market are regularly made by analysts, marketing specialists from different countries as well as by experts from the International Coffee Organization (ICO). The market monitoring data are continually published in the Internet and the press. At the same time the specific actuality of this research is conditioned by necessity of identifying characteristic features and peculiarities of the coffee market functioning within conditions of the current world economic recession.

The aim of this article is a research of the main tendencies of the world coffee market, defining important factors that influence conjuncture of the market most of all, as well as valuation (estimation) of the world financial recession impact on the index numbers of world coffee production and consumption, and set future prospects consumption of the drink.

\section{Results}

Coffee beans of hundreds brands are sold around the world. And each brand depending on the location where it was grown differs on taste, aroma, caffeine content and minerals composition. Nevertheless coffee is divided into two main brands, namely Arabica and Robusta. Thanks to long lasting selection the Arabica coffee beans are considered to be a product of higher quality. This sort is more demanding is cultivation and growing. It is grown on higher (from 600 up to $2000 \mathrm{~m}$ ) comparatively to Robusta (from 0 up to $600 \mathrm{~m}$ ) altitude above sea level. Arabica is milder, has greater aroma and is better balanced than Robusta. Coffee from a Robusta tree contains more caffeine and has stronger flavour.

Statistic data as for coffee production on different continents show a dominant role of South America countries where in 2011/12 harvest year some 58765 thousand bags have been gathered (that is $-6,6 \%$ comparatively to $2010 / 2011$ harvest year). That means that the main coffee continent produces $43,7 \%$ of all coffee beans. Thanks to good harvest in Vietnam and Papua New Guinea and relatively good harvest in India, the Asia and Oceania regions have produced 30,5\% of the world coffee harvest (that is 35956 thousand bags). Mexico and Central America with their result of 19959 thousand bags are third in the world supplier of the coffee beans (14,8\%). The least coffee is produced in Africa. Its part in the world production makes $11,0 \%$ or 14805 thousand bags. Though it should be mentioned that 2011/12 harvest year has not been very successful for African coffee producers - general productivity on the continent has been reduced almost $8,7 \%$ in comparison to the previous year.

It is necessary to note that coffee production is a highly concentrated type of activity. The first five producers (Brazil, Vietnam, Indonesia, Columbia and Honduras) provide more than $66,7 \%$ of the total coffee production. 
According to the data from the International Coffee Organization coffee consumption constantly grows. For instance in 2000/01 people around the world consumed 105,5 million bags of coffee. And ever since then coffee consumption has only been increasing. And in 2008/09 it reached the level of 132,9 million bags which is $20,9 \%$ more than it was consumed in $2000 / 01$. We shall note that even the world economic recession could not make a dramatic impact on the coffee market. The consumption was decreased only 1,1 million bags comparatively to the previous year (that is less than 1\%) and in 2010 it was already $4 \%$ increased. The world leaders in coffee consumption among all countries-consumers in 2011/12 are the USA - 22,0 million bags, Brazil - 19,5 million bags, Germany - 9,4 million bags, Japan - 7,0 million bags and France - 6,0 million bags.

Comparison of coffee world production and consumption from 2000/01 till 2011/12 is illustrated in Graph 1.1.

Graph 1.1. World coffee production and consumption during the period from 2000/01 till 2011/12 harvest years, in million bags. [1, 6, 7]

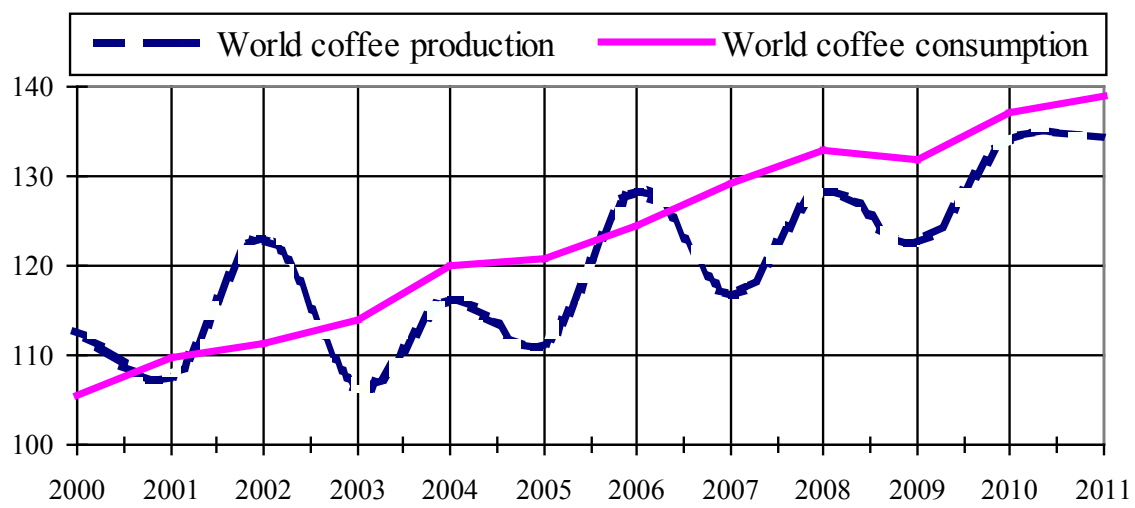

The research shows that during the last decade there is a clear misbalance between demand and offer. Consequently only in 2000, 2002 and 2006 coffee production was greater than demand. All other years the demand on coffee was greater than the harvest. Even though the average coffee production for the period from 2000 till 2012 harvest years made almost 120,2 million bags and exceeded results of the previous decade this increase was not enough to satisfy the growing world consumption of this drink. The average deficit of coffee production in comparison to its consumption during the period being researched made 3,0 million bags that is $2.2 \%$. In other words the demand on coffee was growing faster and was more stable than its general production that is receives bigger and more and more dramatic impact from the global warming. 
In order to establish the future prospects of coffee consumption in the world, based on existing data consumption of coffee harvest in the last years, with economic and mathematical model, we construct a trend line and calculate the predicted values of consumption of the beverage. At the same time, develop three forecast scenarios, namely realistic, pessimistic, optimistic. Accordingly, we first construct a graph on predictive values of the variable Y. In our case - schedule of coffee consumption according to time. Building a trend line by setting all necessary parameters (number of periods to forecast - four (2015/16 harvest year), title, summary equation of a trend line and coefficient of determination $\mathrm{R}^{2}$ ). Note that the coefficient of determination characterizes the degree of closeness trend lines to the original data. It can take values from 0 to 1 , and the higher the value, the better the trend line describes the data. This study will use a linear (arithmetic) approximation - a straight line that best describes the data set and is usually used when the data points are close to the line. It is described by the following equation:

$Y=k x+b(1.1)$

where $\mathrm{x}$ - independent variable (our factor - time); $\mathrm{k}$ and $\mathrm{b}$ - calculated line parameters (parameter $k$ determines the slope of the line; $b$ - point of intersection with the axis $\mathrm{Y}$ ).

The results forecast consumption of coffee in the world by 2015/16 harvest year are shown in Graph 1.2.

Graph 1.2. Scenarios of world coffee consumption during the period from $2012 / 13$ till 2015/16 harvest years, in million bags.

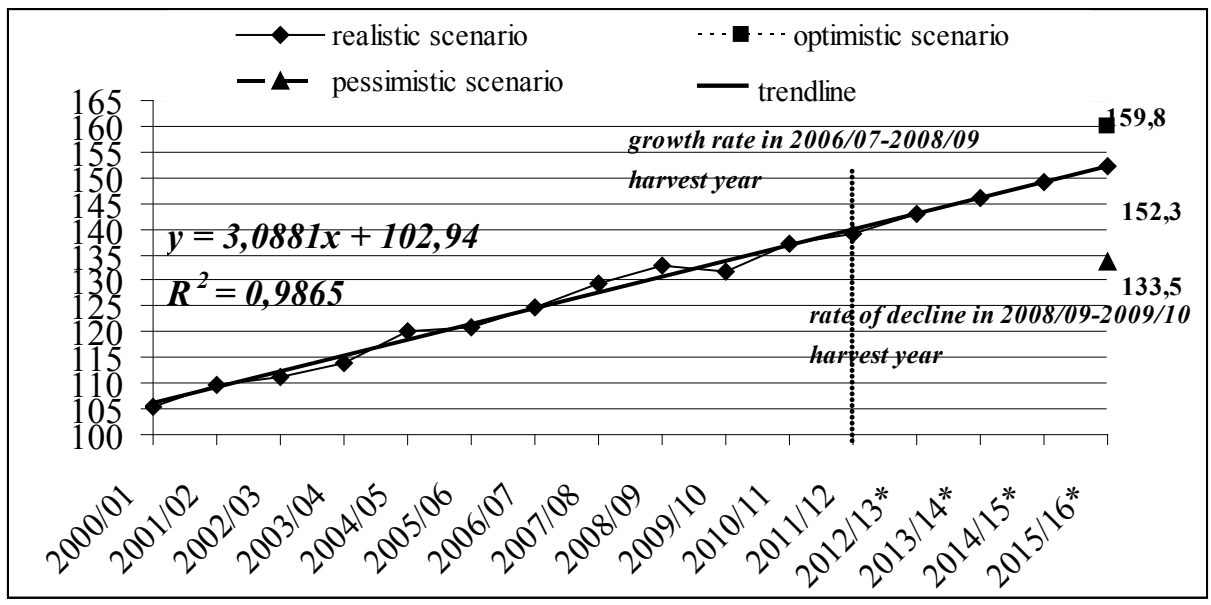

Own research 
Thus, the optimistic scenario, the consumption of coffee in the world in 2015 will reach almost 159.8 million bags, or increase, in comparison with 2011 by $14.5 \%$. In a realistic scenario, the consumption of coffee in 2015 to nearly 13.3 million bags more than the true value of consumption in 2011 and will reach 152.3 million bags. Pessimistic scenario coffee market shows that in 2015 the consumption of this product will be reduced to the level of 133.5 million bags, which is less than in consumption in 2011 by $4.1 \%$.

In our opinion, the consumption of coffee in 2015/16 harvest years will be in the range between optimistic and realistic scenarios, thus, will gravitate to the results of the latter.

As in any consuming market the index numbers of the available reserves are exceptionally important for its stable functioning. The available reserves to a greater extend define price fluctuations as well as its dynamics on the consumption market. During instable periods they protect both the market and consumers in particular from long lasting and heavy crises of prices.

Taking into consideration the instability of coffee beans production with constantly growing demand the certified reserves play more and more important role in the stability of offer and define the price trend that rules the market.

The sales of coffee in the world are mainly made on FOB (free on board) or CIF (cost, insurance and freight) basis. New York is the world capital of coffee sales. Nevertheless big amounts of coffee are stored in European ports such as London, Amsterdam, Hamburg, Bremen and Rotterdam. Correspondingly the two biggest and most important coffee exchanges are located in New York and London. In New York coffee is measured in pounds (lb), 1 pound = 454 gr and in London it measured in tons of coffee.

Coffee reserves are divided into gross reserves of coffee exporting countries and reserves in traditional coffee importing countries (EU, the USA and Japan). Their general dynamics during 2000-2011 is shown in graph 1.3.

Graph 1.3. World dynamics of coffee reserves fluctuations during 2000 - 2011, in million bags. $[16,17]$

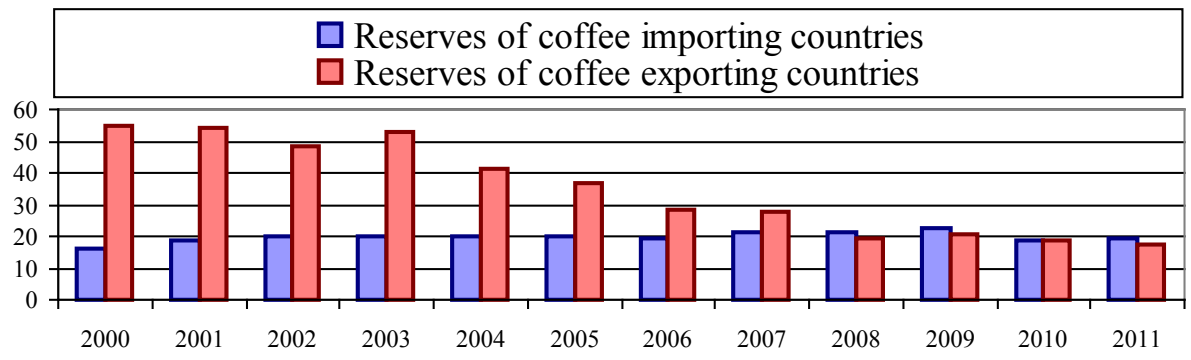


During the period being researched there is a strong tendency of decreasing the available gross coffee reserves. Thus in 2000 general reserves made 71,1 million bags of coffee, in 2005 they were 57,2 million bags and in 2010 they were reduced to the level of 36,9 million bags which is almost twice less than the same index in 2000. And if in traditional coffee markets the reserves are more or less stable and during the last decade they very between 16,0 and 22,4 million bags of coffee, then in countries that export coffee there has been a dramatic reduction of reserves from 55,0 down to 17,5 million bags of coffee. The fact of the matter is that during the last decade the ratio between the demand and offer was not to the favour of the latter. In other words coffee consumption exceeded the production and it influenced the general level of coffee reserves in exporting countries. In conditions of existing high prices which took place from the end of 2009 till 2011 the exporting countries considerably increased dispatching of expensive coffee beans and thus decreased their own reserves but increased export incomes into their economies. On the contrary during the same period the importing countries due to constantly growing demand on coffee increased their own reserves and starting from 2008 the reserves in traditionally importing countries began to exceed the reserves of the exporting countries.

The research of composite indicator price (ICO) from 2000/2001 till $2011 / 2012$ showed that during that period there was a strong tendency of increasing average annual composite indicator price for coffee beans (Graph 1.4.).

Graph 1.4. Dynamics of average annual composite indicator price for coffee beans during 2000/01 - 2011/12, indicated in US cents per pound of coffee beans. [14]

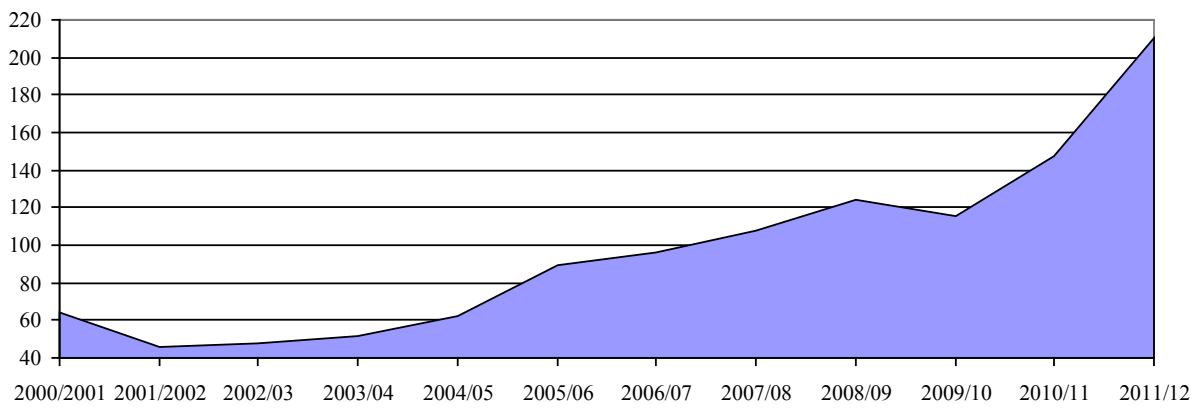

Thus the average annual composite indicator price for coffee in 2001/2002 made 45,59 US cents per pound of coffee beans. And during the following years it has gradually being increased until it reached the point of 124,25 US cents per pound of coffee beans in 2008/09. 
Nevertheless at the end of 2007/08 harvest year the world financial recession began. And till the time when the information about the depth of the impact on the world economy by the recession was not made public by the press the prices for coffee continued to grow. However in the second half of 2008 when the next drop-down of the recession began to sharpen and stock markets were considerably being shaking with fever, the coffee market like other sectors reacted with significant decrease of prices in the forth quarter of 2008.

Dynamics of prices fluctuations starting from 2008/09 harvest year and till January 2013 is indicated in graph 1.5.

Graph. 1.5. Dynamics of composite indicator prices from January 2008 till January 2013, in US cents per pound of coffee beans. $[14,15]$

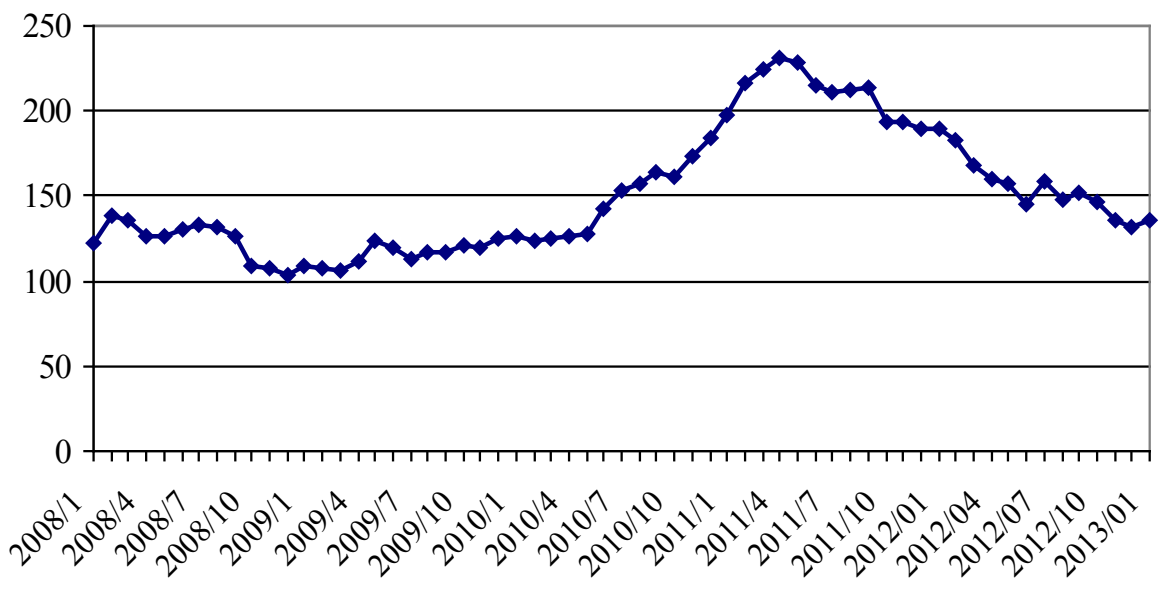

As shown above the drop-down of average monthly composite indicator prices starting from July 2008 till December 2008 made more than 26\%, that is from 131,14 down to 103,7 US cents per pound of coffee beans.

Therefore we can agree with the conclusion of ICO experts regarding the drop-down of prices for coffee beans not being connected to the changes of balance between demand and offer. From our point of view the main reason of such reduction of future contracts popularity as well as total fixing of profits in coffee sector because absorbing recession and credit collapse decreased demand on food staffs and this correspondingly forced investors to withdraw capitals from consuming markets. And consequently the price for the product was corrected.

Experts also indicate the following negative factors which influence the world coffee sector during the economic recession [22]:

- strengthening of US dollar comparatively to the currencies of coffee producing countries; 
- decreasing of bank credit expansion that in middle term period will cause reduction of investments into production and possibly influence the total offer of coffee in the market;

- increasing of the inflation rate both in coffee producing and coffee consuming countries.

However in the beginning of 2009 (in January) the coffee market showed sure increase on $5,2 \%$ having cut off descending of prices that was indicated in the second half of 2008. Having said so, prices for Columbian and Central American coffee were especially increased (supplies of that coffee had dramatically been influenced by the climatic - long lasting rains - as well as other problems). Information about possible reduction of coffee production in Brazil together with low level of reserves have also played a significant role on ascending price dynamics. In February, comparatively to January, the average price for coffee was decreased down to $0,73 \%$. At the same time price for coffee from Columbia, Central America and India didn't decrease. To the information that had been released earlier in January the additional information that Columbian harvest was hard being hit by the plans of the national federation of coffee producers to renew coffee tree plantations [23].

In general it is necessary to indicate that economic recession made the coffee market in 2009 very resembling to the "Russian rides" due to its high unexpectedness and significant price fluctuations. And even though situation on the coffee market in 2009 was instable and average indicative price during the year was decreased from 124,25 down to 115,67 US cents per pound of coffee beans (that is $-7.4 \%$ ) there was not a considerable fall down of prices for coffee beans. On the contrary in October there was a new price increase. Significant support to the prices was given by the weakening of the US dollar (comparatively to the main world currencies) expected reduction of production in Brazil (due to bad harvest), low transit coffee reserves in 2009/10 which according to the data from the Ministry of the agriculture of the USA were decreased down to 30 year minimum [22] and forecasted stability of the demand on coffee in the world. Therefore in 2010 the upper indicated factors also dominated in the sector and significant price increase that began in March 2010 lasted till April 2011. Beginning from May 2011 the ascending trend was changed to the descending. Being afraid of the second wave of the world recession and taking into consideration depressing news from SU, the coffee market experienced new wave of fixing profit. Nevertheless in the short term perspective of the prerequisites to significant reduction of price so far is not observed because the market situation continues to be favourable for supporting high level of prices. According to the experts opinion we cannot expect significant changes of the prices in the nearest future and the price is somewhere between $130-$ 
160 US cents per pound of coffee beans. Adverse weather conditions continue to destroy coffee plantations and complicate transportation of gathered coffee beans in many coffee producing countries, thus having negative impact on short term of coffee offer. The world consumption of coffee continues to demonstrate gradual growth. Therefore we observe a common correction of record prices for coffee beans indicators down to adequate current market situation.

\section{Conclusions}

Summarizing the survey of the world coffee market we can draw the following conclusions:

1. Statistic data as for coffee production on different continents show a dominant role of South America countries. Also it is necessary to note that coffee production is a highly concentrated type of activity. The first five producers (Brazil, Vietnam, Indonesia, Columbia and Honduras) provide more than $66,7 \%$ of the total coffee production.

2. The research shows that during the last decade there is a clear misbalance between demand and offer. The demand on coffee was growing faster and was more stable than its general production that is receives bigger and more and more dramatic impact from the global warming.

3. The consumption of coffee in the world steadily continued to grow. And at the same in spite of the deepest ever since the Great Depression global economic recession, the consumption of this product has not received dramatic dropdown. It is obvious that not the least role in this situation was played by the International Coffee Organization that during almost 50 years actively promotes in the world this drink and propagandizes coffee as essential part of modern life style.

4. The results forecast consumption of coffee in the world by 2015/16 harvest year show that in the optimistic scenario, the global consumption of this product will reach 159,8 million bags, for realistic scenario - 152,3 million bags; pessimistic scenario - 133.5 million bags. But in our opinion, the consumption of coffee in 2015/16 harvest years will be in the range between optimistic and realistic scenarios, thus, will gravitate to the results of the latter.

5. In the modern world the certified reserves play more and more important role in the stability of offer and define the price trend that rules the market. During the period being researched there is a strong tendency of decreasing the available gross coffee reserves. Coffee consumption exceeded the production and it influenced the general level of coffee reserves in exporting countries.

6. The coffee sector comparatively to other markets receives (faces) less impact from economic recession. Thus under the circumstances when the economic 
recession began to sharpen, the average composite price for coffee in 2009 was reduced only $7.4 \%$ in comparison to the previous year. But at the same time it exceeded the 2007 price by the same $7.4 \%$ and correspondingly was higher than all other prices during previous years of the surveyed period of time (that is since 2000).

7. The following sharpening or softening of the situation in the market depends on a number of factors such as coffee productivity, its available reserves and weather conditions as well as ration between demand and offer, interrelations between exporting and importing countries, product prime cost, US dollar exchange rate to the main world currencies or the corresponding scale of recession.

8. Taking into consideration that the increase of prices for coffee beans increases attraction of investments to the coffee sector we can expect that in medium- and long-term perspective the level of prices will face its regular decrease. And coffee production will once again correspond to the demand or might even exceed it.

\section{Bibliography}

Addressing challenges in the world coffee sector. Multi-year Expert Meeting on Commodities and Development. UNCTAD, Geneva, 25-26 January 2012. International Coffee Organization, Dr Denis Seudieu, Chief Economist

ALL EXPORTING COUNTRIES GROSS OPENING STOCKS CROP YEARS 2000/01 TO 2009/10. ICO. // [Online]. - http://dev.ico.org/historical/2000-09/PDF/GROSSOPSTOCKS.pdf

ALL EXPORTING COUNTRIES GROSS OPENING STOCKS CROP YEARS 2010/11 TO 2011/12. ICO. // [Online]. - http://dev.ico.org/historical/2010-19/PDF/GROSSOPSTOCKS.pdf

FAIRTRADE AND Coffee. Commodity Briefing. May 2012. // [Online]. -http://www.fairtrade.org. uk/includes/documents/cm_docs/2012/F/FT_Coffee_Report_May2012.pdf5.

ICO - MONTHLY COFFEE MARKET REPORT : August 2012. // [Online]. - http://ico.heritage4. com/heritage/heridata/ico_pdf_docs/cy2011-12/documents/cmr-0812-e.pdf

ICO - MONTHLY COFFEE MARKET REPORT : June 2012. // [Online]. -http://ico.heritage4.com/ heritage/heridata/ico_pdf_docs/cy2011-12/documents/cmr-0612-e.pdf

ICO - MONTHLY COFFEE MARKET REPORT : November 2012. // [Online]. - http://ico.heritage4. com/heritage/heridata/ico_pdf_docs/cy2012-13/cmr-1112-e.pdf

ICO - The Annual Review for coffee year 2005/06. January 2007. // [Online]. - http://ico.heritage4. com/heritage/heridata/ico_pdf_docs/cy2005-06/documents/review7e.pdf

ICO - The Annual Review for coffee year 2006/07. January 2008 . // [Online]. - http://ico.heritage4. com/heritage/heridata/ico_pdf_docs/cy2007-08/documents/review8e.pdf

ICO - The Annual Review for coffee year 2007/08. January 2009 . // [Online]. - http://ico.heritage4. com/heritage/heridata/ico_pdf_docs/cy2008-09/documents/annual-review-9e.pdf

ICO - The Annual Review for coffee year 2008/09. January 2010 . // [Online]. - http://ico.heritage4. 
com/heritage/heridata/ico_pdf_docs/cy2009-10/documents/annual-review-10e.pdf

ICO - The Annual Review for coffee year 2009/10. March 2011. // [Online]. - http://ico.heritage4. com/heritage/heridata/ico_pdf_docs/cy2010-11/documents/annual\%20review\%2011-e.pdf

ICO - The Annual Review for coffee year 2010/11. February 2012. // [Online]. - http:// ico.heritage4.com/heritage/heridata/ico_pdf_docs/cy2011-12/documents/annual\%20 review\%202010-11e.pdf

ICO INDICATOR PRICES ANNUAL AND MONTHLY AVERAGES: 1998 TO 2012. // [Online]. http://www.ico.org/prices/p2.htm

ICO indicator prices. annual and monthly averages : 1998 to 2013. // [Online]. - http://www. ico.org/prices/p2.htm

IMPORTING COUNTRIES INVENTORIES OF GREEN COFFEE AT THE END OF THE YEAR 31 DECEMBER 2000 TO 2009. ICO. // [Online]. - http://www.ico.org/historical/2000-09/PDF/ Inventories.pdf

IMPORTING COUNTRIES INVENTORIES OF GREEN COFFEE AT THE END OF THE YEAR. ICO. // [Online]. - http://www.ico.org/historical/2010-19/PDF/Inventories.pdf

Outlook for the World Coffee Market International Coffee Council. 24-28 September. International Coffee Organization London, England, Robério Oliveira Silva, Executive Director

Голубева Н. М., Цопа Г. А., Усманова Э. А. Перспективы развития рынка кофе // Вісник Східноукраїнського національного університету імені Володимира Даля. - 2011. - №1 (11). - С. 15-18.

Кунділовська Т.А., Інноваційні підходи до оцінювання якості кави натуральної розчинної // Товарознавство та інновації. - 2011. - Вип. 3. - С. 249-260.

Македон В. В. Формування конкурентних переваг транснаціональних корпорацій у системі міжнародного бізнесу // Науковий вісник: Фінанси, банки, інвестиції. - 2012. - №3. - С. 78-81.

На пути доллара стал кофе. 21.10.09. // [Online]. - http://www.trust.ua/news/17383. html]

Снять сливки с кофе можно как в этом, так и в следующем году. 20.03.09. // [Online]. - http:// www.coffe-tea.ru/export_news.php?itemId $=6482 \&$ docId $=3338$ 